\title{
Tuberculosis in bovine slaughtered in the semi-arid region of Rio Grande do Norte, Brazil
}

\section{Tuberculose em bovinos abatidos no semiárido do Rio Grande do Norte, Brasil}

\author{
Pirajá Saraiva Bezerra Neto1; Flábio Ribeiro de Araújo²; Taynara Nunes Pasquatti; \\ Felício Garino Junior3; Giovanni Brito Medeiros ${ }^{1}$; Millena de Oliveira Firmino4; \\ Rosália Severo de Medeiros ${ }^{5}$; Severino Silvano dos Santos Higino6*
}

\section{Highlights}

The samples exhibited amplification for the M. bovis.

Microbiological culture may present false-negative results.

The animals positive represents a risk from the point of view of public health.

\begin{abstract}
Between November 2017 and August 2018, in order to determine the occurrence of tuberculosis in cattle slaughtered in the semi-arid region of Rio Grande do Norte, 11,610 bovine carcasses underwent a routine post-mortem inspection. One animal presented suggestive lesions and samples from lung, spleen and heart were submitted to microbiological culture in Stonebrink medium for 90 days and molecular analysis by nested-PCR. For histopathological examination and Ziehl Neelsen staining, the omentum was used. In the cultured samples, two of them (heart and spleen) showed growth, but were not confirmed as $M$. bovis by conventional PCR. At nested-PCR, the samples showed amplification for the TbD1 region. The presence of numerous granulomas was detected in the histopathological examination characterized by a necrotic center and areas of mineralization, as well as the presence of acid-fast bacilli (AFB) in the ZiehlNeelsen stain. Microbiological culture can show false negative results, despite being considered a gold standard technique, although it takes time. Nested-PCR and histopathology show fast and effective results for the diagnosis of the disease. The presence of positive animals represents a public health risk in the

1 Students of the Master's Course of the Graduate Program in Animal Science, Universidade Federal de Campina Grande, UFCG, Patos, PB, Brazil. E-mail: pirajamedvet@gmail.com; gbmvet@gmail.com

2 Researchers at Empresa Brasileira de Pesquisa Agropecuária, EMBRAPA, Campo Grande, MS, Brazil. E-mail: flabio. araujo@embrapa.br; tay.pasquatti@gmail.com

3 Prof. Dr., Graduate Program in Animal Science, Universidade Federal da Paraíba, UFPB, Areia, PB, Brazil. E-mail: garinofj@@hotmail.com

${ }^{4}$ Student of the Doctoral Course of the Graduate Program in Science and Animal Health, UFCG, Patos, PB, Brazil. E-mail: millena_deoliveira@yahoo.com.br

5 Profa Dra, Course in Biological Sciences, UFCG, Patos, PB, Brazil. E-mail: medeiros.rsm@gmail.com

${ }^{6}$ Prof. Dr., Graduate Program in Animal Science, UFCG, Patos, PB, Brazil. E-mail: severino.silvano@professor.ufcg.edu.br

* Author for correspondence
\end{abstract}

Received: Sept. 15, 2020 - Approved: June 02, 2021 
studied region. Therefore, one of the essential systems applied to the control of bovine tuberculosis is the epidemiological surveillance of animals in slaughterhouses.

Key words: Mycobacterium bovis. Public health. Slaughterhouses. Tuberculosis.

\section{Resumo}

Entre novembro de 2017 e agosto de 2018, com objetivo de determinar a ocorrência de tuberculose em bovinos abatidos no semiárido do Rio Grande do Norte, 11.610 carcaças de bovinos passaram por inspeção post-mortem de rotina. Um animal apresentou lesões sugestivas e amostras de pulmão, baço e coração foram submetidas ao cultivo microbiológico em meio Stonebrink por 90 dias e análise molecular pela nested-PCR. O omento foi utilizado para exame histopatológico e coloração de Ziehl Neelsen. Nas amostras cultivadas, duas (coração e baço) evidenciaram crescimento, mas $M$. bovis não foi confirmado na PCR convencional. Já na nested-PCR, as amostras exibiram amplificação para a região TbD1. Foi detectada a presença de inúmeros granulomas no exame histopatológico caracterizados por possuírem um centro necrótico e áreas de mineralização, bem como a presença de bacilos Álcool-ácido resistentes (BAAR) na coloração de Ziehl-Neelsen. A cultura microbiológica pode apresentar resultados falso-negativos, apesar de ser considerada uma técnica padrão-ouro, embora demorada. A nested-PCR e a histopatologia apresentam resultados rápidos e eficazes para o diagnóstico da enfermidade. A presença de animais positivos representa um risco a saúde pública na região estudada. Portanto, um dos sistemas essenciais aplicados ao controle da tuberculose bovina é a vigilância epidemiológica dos animais em abatedouros.

Palavras-chave: Abatedouros. Mycobacterium bovis. Saúde pública. Tuberculose.

The semi-arid region of Rio Grande do Norte stands out for its bovine breeding. This activity contributes to the creation of jobs and income, as well as the settlement of people in the countryside. However, low technology, consecutive years of drought and infectious diseases have hampered this development (Secretaria de Planejamento do Rio Grande do Norte [SEPLAN], 2016).

The bovine tuberculosis presents a chronic evolution and is characterized by granulomatous lesions located predominantly in the respiratory tract (Bica, Copetti, \& Brum, 2018).

In Brazil, the National Program for the Control and Eradication of Brucellosis and Animal Tuberculosis (PNCEBT) was instituted in 2001 and updated in 2017 by Normative Instruction n010/2017 (Ministério da Agricultura Pecuária e Abastecimento [MAPA], 2017). After 15 years of its creation, the epidemiological situation of bovine tuberculosis was detailed in 13 states of the federation, but the state of Rio Grande do Norte had no data published in the study (Ferreira et al., 2016).

Of the control measures recommended by the PNCEBT, sanitary inspection in slaughterhouses is of great importance for public health, since it promotes the removal of meat contaminated with the pathogenic microorganisms, since uncoated animal carcasses end up going into clandestine commerce and serving as food for the population (Ramos et al., 2016). 
Several studies carried out in slaughterhouses in Brazil have shown the occurrence of disease in animals. However, the Rio Grande do Norte state has no official data on the actual health status of the herd, which has contributed to the devaluation of the local cattle.

Thus, the present work aimed to determine the presence of Mycobacterium bovis in bovine slaughtered in public slaughterhouses of the semiarid of Rio Grande do Norte, Brazil.

The Animal Use Ethics Committee of the Federal University of the Campina Grande (protocol 107/2017), authorized this study.

Rio Grande do Norte is divided into 167 municipalities with a geographical area of $52,000 \mathrm{~km}^{2}$ (SEPLAN, 2016). This is work was carried out in two slaughterhouses of the State, holders of the Municipal Inspection Service (SIM), located in the municipality of Caicó (latitude: 6 27 '30 'S; longitude: 37 05' 52" W) and Jardim do Seridó (latitude: $6^{\circ} 35$ '04 'S, longitude: $36^{\circ} 46^{\prime}$ ' 28" W), intermediate geographic region of Caicó, semi-arid of the State.

Between November 2017 and August 2018, all bovine animals that were slaughtered underwent routine inspection. In the postmortem, all the carcasses were inspected in the different lines, having their main organs and lymph nodes incised. The carcass that presented lesions suggestive of tuberculosis had samples collected, packaged in sterile, hermetically sealed flasks, duly identified and sent in an ice cube box to the Laboratory of Vaccines and Diagnosis at the Center for Health and Rural Technology of the Federal University of Campina Grande, Campus in Patos - Paraíba (LAVADI/CSTR/UFCG), where, under biosecurity conditions, they were subdivided into duplicates and frozen. Subsequently, an aliquot was sent to the Immunology Laboratory, located at the Embrapa Beef Cattle, Campo Grande-Mato Grosso do Sul, to perform the microbiological and molecular diagnosis and the second part was sent for histopathological examination in the Laboratory of Pathological/ Histopathological Anatomy from the UFCG (LPA/CSTR/UFCG), fixed in formaldehyde 10\%.

The lesions suggestive of tuberculosis were thawed and minced with the aid of a scalpel in smaller sizes, placed in tubes containing ceramic beads (MagNA Lyser green beads tube). $1 \mathrm{ml}$ of distilled water was added and the mixture was stirred in the MagNA Lyser instrument (Roche, Mannheim, Germany) for 30 seconds at $6.000 \mathrm{rpm}$. The aqueous fraction was removed, transferred to sterile and decontaminated $2 \mathrm{ml}$ tubes using the Petroff method (Petroff, 1915). Cultivation was prepared by instilling 6 drops of each inoculum in duplicate into the tubes with Stonebrink medium and incubated at $37^{\circ} \mathrm{C}$ in a bacteriological oven being monitored for 90 days.

DNA extraction from the lesions was performed using the DNEasy Blood \& Tissue Kit (Qiagen, Hilden, Germany) according to the protocol recommended by the manufacturer. The quality and concentration of the DNA sampleswere evaluated byspectrophotometry on NanoDrop ND-2000 (Thermo Scientific, Wilmington, USA) (Araújo et al., 2014).

According to Araújo et al. (2014), this technique aims at the amplification of the TbD1 region using a first amplification of the genomic region by conventional PCR, followed by amplification of the product of the first one (re-amplification), using real-time 
PCR by nested-PCR. This region comprises the mmpS6 gene, which codes for a probable conserved membrane protein, and the 5 'region of the mmpL6 gene. TbD1 is present in $M$. bovis (including BCG strains), Mycobacterium africanum, $M$. canettii and absent in modern M. tuberculosis isolates. Conventional PCR (step 1) was performed in a final volume of $25 \mu \mathrm{l}$, containing $10 \mathrm{mM}$ Tris- $\mathrm{HCl}(\mathrm{pH} 8.3), 50 \mu \mathrm{M}$ $\mathrm{KCl} ; 1.5 \mathrm{mM} \mathrm{MgCl} 2,0.2 \mathrm{mM}$ of each dNTP, $7.5 \mathrm{pmol}$ of each primer, $1.25 \mathrm{U}$ of Taq DNA polymerase and 3.0 $\mu$ l of DNA. Amplifications were performed on a MJ Mini Thermal Cycler thermal cycler (BIO-RAD, California, USA). Initial denaturation was performed at $95^{\circ} \mathrm{C}$ for 4 minutes, followed by 35 cycles of denaturation at $95^{\circ} \mathrm{C}$ for 90 seconds, annealing at $65^{\circ} \mathrm{C}$ with 35 cycles for 30 seconds and extension at $72^{\circ} \mathrm{C}$ for 45 seconds. A single final extension step of $72^{\circ} \mathrm{C}$ was performed for 3 minutes. The external forward primers Mb: 5'-GTGGCG GTCGCGGGATTCAGᄀCGTCTAT-3' and outer reverse Mb: 5'-TTATGGCGGCCACACCCACC CAAAACAG-3' were used, which amplify a 474bp fragment of the TbD1 region.

The real-time PCR (step 2) was performed in final volume of $12.5 \mu$, containing $6.25 \mu \mathrm{l}$ of Taqman Master Mix (ref. 4352042, Applied Biosystems, California, USA), 600nM of each primer, 100nM probe and $3 \mu$ of the standard PCR product. Amplifications were performed on a StepOnePlus thermal cycler (Applied Biosystems, California, USA). Initial denaturation was performed with one cycle at $95^{\circ} \mathrm{C}$ for 10 minutes followed by 35 cycles of denaturation at $95^{\circ} \mathrm{C}$ for 15 seconds and annealing/extension at $62^{\circ} \mathrm{C}$ for 30 seconds. In this reaction, the internal forward primers $\mathrm{Mb}$ : 5'-GCGGTCTTCGCCAATGTT-3' and internal reverse Mb: 5'-GCAGCCGATGGAATTGCT-3'; and the probe Mb: 6FAM-CGCGCAAGGCGAMGBNFQ were used, which amplify a fragment of $51 \mathrm{bp}$.

For all nested-PCR reactions, a positive control was used with $M$. bovis AN5 DNA, a negative control with a $M$. tuberculosis H37Rv sample, and a blank control containing all the reagents of the reaction mix, minus the DNA that is replaced by equal volume of ultrapure water. It is valid to postulate that, in order to avoid contamination of the preparation of the mix and the pipetting of DNA, the whole process took place inside a specific cabinet for PCR.

The cultures had aliquots transferred to $1.5 \mathrm{ml}$ microtubes, where $200 \mu \mathrm{l}$ TE buffer was added and incubated for 60 minutes at $87.5^{\circ} \mathrm{C}$ for inactivation of the colonies. After the inactivation process, $200 \mu$ of bacterial suspension was used in the DNA extraction process. Sixty microliters of lysozyme $(10 \mathrm{mg} /$ $\mathrm{ml}$ ) were added to the samples. The mixture was incubated for 120 minutes at $37^{\circ} \mathrm{C}$. In order to break down the proteins, $30 \mathrm{ml}$ of Proteinase $\mathrm{K}(10 \mathrm{mg} / \mathrm{ml})$ and $60 \mathrm{ml}$ of $10 \%$ SDS were added to the samples. Samples were incubated at $56^{\circ} \mathrm{C}$ for 240 minutes. Four hundred microliters of saturated phenol pH 8.0 and $15 \mu$ l of isoamyl alcohol were used to remove the proteins from the solution. Each sample was centrifuged at 700rpm for 5 minutes at environmental temperature. The supernatant (aqueous phase) was removed and transferred to a new tube. DNA precipitation was performed using $275 \mu \mathrm{l}$ of absolute ethanol and $15 \mu$ l of 2-propanol. The samples were centrifuged at 19.000rpm for 10 minutes at $4^{\circ} \mathrm{C}$. After discarding the supernatant, the precipitate was washed with $500 \mu \mathrm{l}$ of $70 \%$ ethanol and the tube was homogenized by inversion. The sample was 
again centrifuged at 19.000rpm for 10 minutes at $4^{\circ} \mathrm{C}$ and the supernatant was discarded. The DNA was dried and resuspended in $50 \mu \mathrm{TE}$ buffer (Sales et al., 2014).

The standard PCR reaction of the colonies was performed in a final volume of $25 \mu$ containing $10 \mathrm{mM}$ Tris- $\mathrm{HCl}(\mathrm{pH} 8.3), 1.5 \mathrm{mM}$ $\mathrm{MgCl}_{2}, 0.2 \mathrm{mM}$ of each dNTP, 7.5pmol of each primer, $1.25 \mathrm{U}$ of Taq DNA polymerase and $2.0 \mu \mathrm{l}$ of DNA. Amplifications were performed on a MJ Mini Thermal Cycler (BIO-RAD, California, USA). Initial denaturation was performed at $95^{\circ} \mathrm{C}$ for 4 minutes, followed by 35 cycles of denaturation at $95^{\circ} \mathrm{C}$ for 30 seconds, annealing at $56^{\circ} \mathrm{C}$ with 35 cycles for 30 seconds and extension at $72^{\circ} \mathrm{C}$ for 30 seconds. A single final extension step of $72^{\circ} \mathrm{C}$ was performed for 5 minutes. Outer forward primers Mb.400: 5'-AACGCGACGACCTCATATTC-3' and outer reverse Mb.400: 5'-AAGGCGAACAGATTCA GCAT-3' were used. Amplified PCR products were all subjected to $2 \%$ agarose gel electrophoresis stained with ethidium bromide $(0.5 \mu \mathrm{g} / \mathrm{ml})$ (Araújo et al., 2014).

During the period of collection, 11,610 carcasses (7,882 males and 3,728 females) were submitted to post-mortem inspection, when one animal showed lesions suggestive of tuberculosis. The animal came from a dairy farm of the municipality of Caicó, created in the semi extensive system, it was an adult female that had a good body score. The lesions were mainly located in organs and tissues of the thoracic and abdominal cavities. The lesions in the lung were characterized by firm, whitish and encapsulated nodules, $2-3 \mathrm{~cm}$ in diameter and filled with caseous material. In the heart, calcified multiple lesions and in variable sizes could be observed. In the spleen, a number of granulomatous nodules with a purulent or caseous aspect were found, with a fibrous capsule and, in some cases, calcification in the center of the lesion, as evidenced by the knife grinding at the cut. In the omentum, multiple granulomas, yellowed, well delimited and firm, were observed in the post-mortem inspection, which, when cut, were filled with caseous material and with knife grinding at the cut.

In the histopathological exam of the omentum, we observed multiple granulomas, characterized by multifocal areas with central necrosis coalescents surrounded by a marked mononuclear inflammatory infiltrate, predominantly composed of macrophages, epithelioid macrophages, multinucleated giant cells and, to a lesser extent, plasma cells and lymphocytes, coated by a thick capsule of fibrous connective tissue (Figure 1). In some areas of necrosis, deposition of strongly basophilic granular material (mineralization) was observed. The presence of acid-fast bacilli (AFB) was detected in the Ziehl-Neelsen stain in the cytoplasm of macrophages and in the middle of the necrosis. 

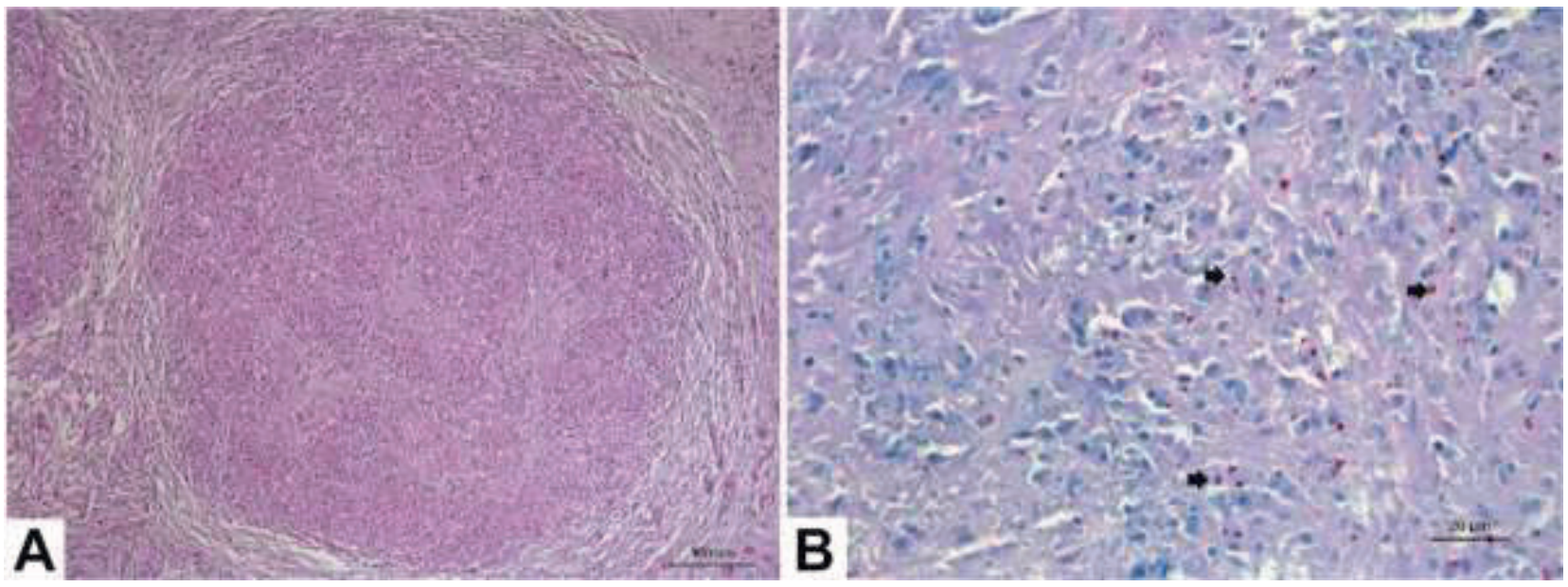

Figure 1. Tuberculosis in cattle (A) Omentum, granuloma is seen consisting of a central area of necrosis associated with a marked inflammatory infiltrate consisting of macrophages, multinucleated giant cells, epithelioid cells and plasma cells surrounded by fibrous connective

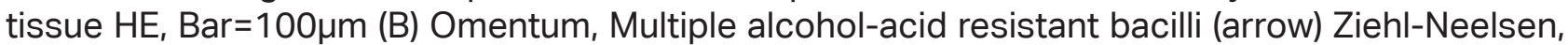
Bar $=20 \mu \mathrm{m}$.

The lung, heart and spleen samples, analyzed by nested-PCR, were considered positive, since they exhibited amplification for the TbD1 region of $M$. bovis (Figure 2). Regarding the culture in Stonebrink medium, two samples (heart and spleen) evidenced growth of colonies, but were not confirmed as being of $M$. bovis by conventional PCR. The tissue samples presented agreement with positive results, both in histopathology and nested-PCR. The animals slaughtered in the establishments studied come from all the mesoregion in which they are situated. The presence of animals tested positive for tuberculosis represents a risk from the point of view of public health, since the ingestion of contaminated meat is the cause of several diseases that will cost directly to the health systems and indirectly to the work capacity.

The low frequency found in the study was already expected, since the semiarid of Rio Grande do Norte is facing the occurrence of an intense drought in recent years, which caused a significant reduction in the cattle herd, due also to the fact that animals slaughtered are mostly young. Araújo et al. (2014) and Pereira et al. (2017), report the chronicity of the disease, being observed, in most cases, in adult animals. It is important to highlight that Rio Grande do Norte has a low number of slaughterhouses with the Municipal Inspection Service. According to the Institute of Defense and Agricultural Inspection of Rio Grande do Norte (IDIARN), no cattle slaughterhouse is permanently inspected by the agency in the State.

With the exception of Rio Grande do Norte, several studies were conducted in 13 States in order to characterize the epidemiological situation of bovine tuberculosis. In the milk-producing belt in Brazil, Espírito Santo, north of São Paulo, south of Minas Gerais and south of Goiás, the highest values of disease prevalence were 
observed (Ferreira et al., 2016). This fact is related to the increase in population density during the management (Veloso et al., 2016).
Facilities that have a poor ventilation system can also contribute to the increase in cases of the disease (Mekonnen et al., 2019).

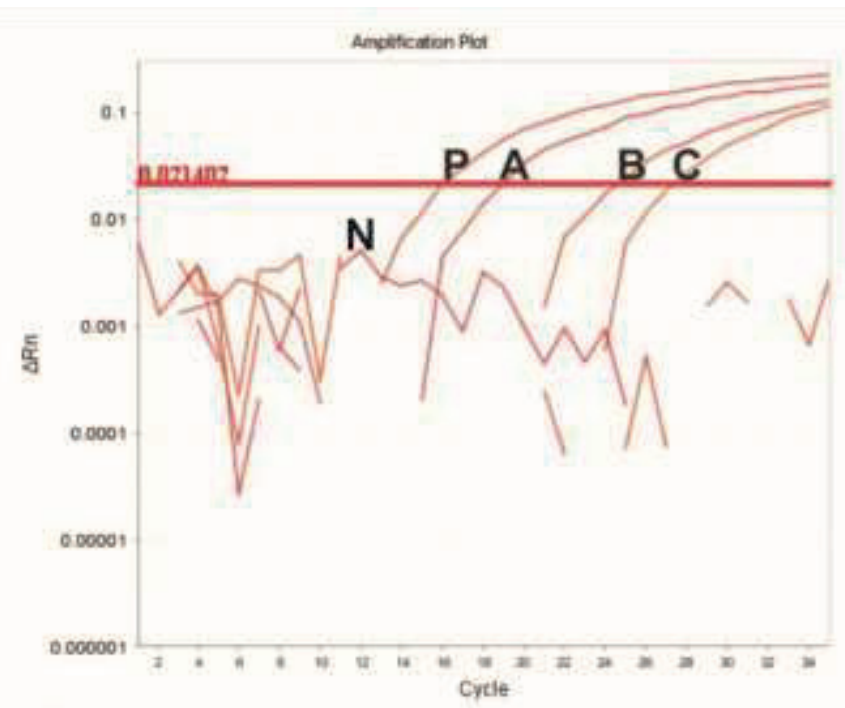

N- Negative Control

P- Positive Control (Ct: 18.8)

A. lung (Ct: 16.0)

B - heart (Ct: 24.5)

C - spleen (Ct: 27.3)

Figure 2. Nested-PCR. Samples showing nested-PCR amplification for Mycobacterium bovis TbD1.

It is necessary to point out that in Rio Grande do Norte, the cattle breeding is predominantly of dairy herds, where $79 \%$ of the establishments are characterized as family farming, in which $44 \%$ of the state production of bovine milk is produced. Generally, the dairy activity practiced by this breeding model, is characterized by low technological level, adopting less intensive production systems, with little use of capital, diversified production and use of resources available in the productive unit itself (SEPLAN, 2016).

The lesions found in this research are reported to be the most common form of disease observed at post-mortem inspection in cattle (Bica et al., 2018). In a similar study carried out by Ramos et al. (2016), at the post-mortem inspection, lesions suggestive of tuberculosis were characterized by focal, multifocal or diffuse nodules, with a caseous appearance and a gritty cut surface in various organs and tissues. In these, the identification of $M$. bovis could be confirmed with histopathological examination, microbiological culture, Ziehl-Neelsen staining and molecular analysis.

In the present study, one of the methods used to diagnose the lesions was nested-PCR. In order to amplify the TbD1 region (conserved part of $M$. bovis), all samples submitted to the test showed positive results. In a study carried out by Araújo et al. (2014), in Campo Grande-Mato Grosso do Sul, with lesions collected from bovines and buffaloes in several slaughterhouses of the country, it was observed that nested-PCR allowed 
the identification of $M$. bovis in tissues with similar or superior performance to the culture and in a short time. Furlanetto et al. (2012), using multiple PCR directly on tissue fragments, detected the presence of $M$. bovis in $7 \%(14 / 182)$ of the lesions, demonstrating greater sensitivity of the molecular test when compared to the microbiological analysis (1.5\%).

The inspection performed by the traditional method in this research, through the incision of the main organs and lymph nodes, may represent a risk to the health of the official veterinarian, the carcass and the environment. On the basis of this evidence, the European Commission published the regulation 219/2014. With this regulation, post-mortem inspection in domestic pigs was only visual, and incision and palpation of the carcass and offal were performed when signs and clinical lesions could indicate a possible risk (Ghidini et al., 2018).

Silva et al. (2018), evaluating the risk factors of zoonotic tuberculosis in Brazil, associated the cases found to occupational exposure and consumption of milk and nonpasteurized derivatives, since these behaviors put individuals in contact with the animals and their excretions/secretions directly and indirectly. It is extremely important to consolidate the PNCEBT in Brazil in order to reduce the negative impact that diseases cause and make livestock farming in the country more competitive.

In establishments where the occurrence of the disease is low, identification of infected animals becomes even more difficult. It is essential that the producer only acquires negative animals in the intradermal test. At present, there is no diagnostic method, ante or post-mortem, capable of identifying all infected animals. Detection is improved when different diagnostic methods such as molecular, microbiological and histopathological are combined.

The presence of positive animals represents a risk to public health. Microbiological culture may present falsenegative results, despite being considered a gold-standard technique, although timeconsuming. Nested-PCR and histopathology showed fast and effective results for the diagnosis of the disease. The surveillance on slaughterhouses is a fundamental system for tuberculosis control.

\section{Acknowledgments}

For the Laboratory of Immunology, Embrapa Beef Cattle, Campo Grande-MS and for the Laboratory of Pathological/ Histopathological Anatomy from UFCG for the support. We also thank Gisele Olivas de Campos Leguizamon for the technical support. This study was supported by the following grants: Embrapa 02.13.10.008.00.00, Fundect 085/2015, 59/300.121/2015 and CNPq 407826/2018-1.

\section{References}

Araújo, C. P., Osório, A. L. A. R., Jorge, K. S. G., Ramos, C. A. N., Souza, A. F., Fo., Vidal, C. E. S.,... Araújo, F. R. (2014). Detection of Mycobacterium bovis in bovine and bubaline tissues using nested-PCR for TbD1. Plos One, 9(3), 6. doi: 10.1371/ journal.pone.0091023 
Bica, R. F. P., Copetti, M. V., \& Brum, M. C. S. (2018). Hydatidosis, cysticercosis, and tuberculosis rates in bovine slaughtered under state sanitary inspection in Rio Grande doSul,Brazil. Ciência Rural, 48(8),17. doi: 10.1590/0103-8478cr20170811

Ferreira, J. S., Neto., Silveira, G. B. da S., Rosa, B. M., Gonçalbes, V.S.P., Grisi, J.H., Fo.,Amaku, M.,... Lage, A. P. (2016). Analysis of 15 years of the National Program for the Control and Eradication of Animal Brucellosis and Tuberculosis, Brazil. Semina: Ciências Agrárias, 37(5), 3385-3402. doi: 10.5433/ 1679-0359.2016v37n5Supl2p3385

Furlanetto, L. V., Figueiredo, E. E. S., Conte, C. A., Jr., Carvalho, R. C. T., Silva, F. G. S., Silva, J. T.,... Paschoalin, V. M. F. (2012). Uso de métodos complementares na inspeção post mortem de carcaças com suspeita de tuberculose bovina. Pesquisa Veterinária Brasileira, 32(11), 1138-1144. doi: 10.15 90/S0100-736X2012001100011

Ghidini, S., Zanardi, E., Di Ciccio, P. A., Borrello, S., Belluzi, G., Guizzardi, S., \& lanieri, A. (2018). Development and test of a visualonly meat inspection system for heavy pigs in Northern Italy. BMC Veterinary Research, 14(1), 1-11. doi: 10.1186/s129 17-017-1329-4

Mekonnen, G. A., Conlan, A. J. K., Berg, S. Ayele, B. T., Alemu, A., Guta, S.,... Ameni, G. (2019). Prevalence of bovine tuberculosis and its associated risk factors in the emerging dairy belts of regional cities in Ethiopia. Preventive Veterinary Medicine, 168, 81-89. doi: 10.1016/j.prevetmed.20 19.04 .010

Ministério da Agricultura, Pecuária e Abastecimento (2017). Secretaria de Defesa Animal. Instrução Normativa SDA $n^{\circ} 10$, de 3 de Março de 2017. Recuperado de https://www.gov.br/agricultura/pt-br/ assuntos/sanidade-animal-e-vegetal/ saude-animal/programas-de-saudeanimal/pncebt/principais-normaspncebt/in-10-de-3-de-marco-de-2017aprova-o-regulamento-tecnico-dopncebt.pdf/view.pdf

Pereira, J. D. B., Cerqueira, V. D., Bezerra, P. S., Bezerra, D. K. O., Araújo, F. R., Dias, A. de C. L.,... Riet-Correa, G. (2017). Diagnóstico histopatológico e molecular de lesões sugestivas de tuberculose em búfalos abatidos nos municípios de macapá e santana, estado do amapá. Pesquisa Veterinária Brasileira, 37(11), 11981204. doi: 10.1590/s0100-736x2017001 100003

Petroff, S. A. (1915). A new and rapid method for the isolation and cultivation of tubercle bacilli directly from the sputum and feces. Journal of Experimental Medicine, 21(1), 38-42. doi: 10.1084/jem.21.1.38

Ramos, J. M., Heinemann, M. B., Ferreira, J. S., Neto., Souza, A. F., Fo., Cárdenas, N. C., Dantas, A. F. S.,... Azevedo, S. S. (2016). Isolamento e identificação de Mycobacterium bovis em bovinos positivos no teste de tuberculinização no estado da Paraíba, nordeste do Brasil. Arquivos do Instituto Biológico, 85(e0842016), 1-7. doi: 10.1590/180816 57000842016

Sales, M. L., Fonseca, A. A., Jr., Sales, É. B., Cottorello, A. C. P., Issa, M. A., Hodon, M. A.,... Heinemann, M. B. (2014). Evaluation of molecular markers for the diagnosis of Mycobacterium bovis. Folia Microbiologica, 59(5), 433-438. doi: 10.1007/s12223-014-0317-3 
Secretaria de Planejamento do Rio Grande do Norte (2016). Diagnóstico e planejamento estratégico para o desenvolvimento de atividades produtivas agrícolas do Rio Grande do Norte. Recuperado de http:// www.rnsustentavel.rn.gov.br

Silva, M. R., Rocha, A. daS., Araújo, F. R., Fonseca, A. A., Jr., Alencar, A. P. de, Suffys, P. N.,... Guimarães, M. D. C. (2018). Risk factors for human Mycobacterium bovis infections in an urban area of Brazil. Memórias do Instituto Oswaldo Cruz, 113(8), 1-6. doi: 10.1590/0074-02760170445
Veloso, F. P., Baumgartem, K. D., Mota, A. L. A. D. A., Ferreira, F., Ferreira, J. S., Neto., Grisi, J. H., Fo.,... Gonçalves, V. S. P. (2016). Prevalence and herd-level risk factors of bovine tuberculosis in the State of Santa Catarina. Semina: Ciências Agrárias, 37(5), 3659-3672. doi: 10.5433/1679-03 59.2016v37n5Supl2p3659 